\title{
The Impact of Political Competition on Countries' Economic Development Through the Public Decision-Making Processess
}

\author{
Annunziata Calabrese* \\ University of Messina, Italy \\ Submission: August 03, 2020; Published: September 08, 2020 \\ "Corresponding author: Annunziata Calabrese, University of Messina, Italy
}

JEL Classification: D02; E02; 043; 044; D72

Keywords: Institutions; Political Competition; Inefficiency; Economic Development; Market; Monopolistic; Public policies; Oligopolistic

\section{Introduction}

The economic models that analyse the functioning of market economies assume the existence of institutions - not necessarily economic - which are essential for the functioning of the markets, whether they are competitive, oligopolistic or monopolistic. Without these institutions, markets would cease to function or be subject to huge inefficiencies. In a constantly evolving globalizaation's context, the presence of effective and efficient governance becomes a strategic necessity for a country and, in this viewpoint, also includes the analysis of the distinctive characteristics. In fact, a well-defined system of property rights, a regulation bureaucracy of markets which guarantees competition, public policies that support social cohesion, political institutions that reduce the risk of social conflicts and/or allow their management, are all institutions functional to the economic growth of a country. The role of institutions in the countries' development process has long interested and continues to attract the attention of the scientists who belong to different disciplinary fields. There is a growing consciousness among scholars on whether the way societies are organized (in the most common sense their institutions) is the primary cause of their economic performance. Three different types of theories analyse the institutions' origins and development. According to economic theories, institutions are configured as efficient insofar as the benefits deriving from them, are greater than their costs [1] or when they reduce uncertainty and therefore transaction costs [23 ] or even they are not necessarily created to be efficient but for serving and preserving the interests of some social groups and for generating new institutions [4-9]. Political theories believe that institutions and policies are introduced for the achievement of benefits by those politically more powerful groups, to consolidate their power and accumulate resources [10]; according to Marx, for example, society was divided into social classes and (economic) policies were designed by the dominant social class, while, modern theories believe that institutions (and policies) are determined by sovereigns, bureaucrats, dominant ethnic and religious groups and lobbies. Finally, according to cultural theories, some societies form beliefs or ideas that can lead to economically "good" (efficient) institutions, while others do not [11-14]. An example of it, which can become institutions, is the "trust in others" (namely in unknown people) that can facilitate collective actions and, therefore, the institutions that lead to the provision of public goods. Over the years, the economic theories of development leave the neoclassical paradigm and identify in the different types of institutions (formal or informal, economic or political) "what matter" for the growth dynamic of a nation. For example, it can be observed how in the planisphere the increases of per capita GDP are concentrated in the temperate areas, far from the equator, so the growth of GDP, according to the economist Sachs [15], is somehow related to the density of coastal population and is attributable to its geographical factors, whereas, the opinion of Acemoglu, who studied their connection with the national economic development, one of the most cited economists in the field of institutional theories, is opposite to. He tries to demonstrate that the economic growth, and therefore the same gap among advanced and developing countries, is due to nothing more than differences between institutions and their histories. According to the author, the political-economic institutional 
bureaucracy of a country arises as a main and non-competing factor (such are the other factors such as capital, land, labour) of a country's economic development (Acemoglu and Robinson, 2012: "Why Nations Fail: The Origins of Power, Prosperity, and Poverty). Obviously, the exponents of these theories are often compared each other not because their respective theses are not supported by any evidence, but because they unsatisfactorily reduce the complexity of reality, leaving out of their capacity to explain those behaviours that, however, represent the basic postulates in other theories. Whether or not they are the main or transversal cause of growth, several viewpoints agree by establishing that "the inadequacy" or low resilience of institutions with a change of environmental conditions or about power relationship among social groups, does not support technology investment, skills and knowledge which are essential to produce the desirable results. One of the primary causes of institutional inefficiencies can be precisely found in the changes in power relationships among social groups where the desire of an internal resource redistribution from the political groups in power leads to the implementation of distorting policies, causing the emergence of institutions that limit growth and improve social inequalities. The conflict among the groups encourages society to bring out political institutions which, through inefficient policies, will be long consolidated even if in the system alternative and better policies coexist. This conflict takes place mainly in the arena of political competition, the latter is therefore the key element in the analysis on a system's institutional arrangements efficiency.

It follows that, political competition represents both a theoretical base and a tool to empirically investigate the reality in which administrators and policies are in time and space connected by reflecting the socio-economic models of the geographical areas examined. The analysis of the relationship between institutions and political competition among groups, is useful to identify how the optimal level of development of a country can be invalidated by political competition variations and policies implications. It is precisely from the definition of political competition that this work start to glimpse the transposition into institution of the individual dimension and the consequences of an action which is implemented in the human case as well as in the institutions, and that declines its effects through a decision. One of the goals of this short essay is, therefore, the capacity to pop the question on how, under some circumstances, the interests conflict among power groups, which become multitudes (institution), may become a set of policies set up to configure a high-performance economic system, for this, the relevance of the relationship between political competition and institutional quality will be here exposed. Several opinions lead to different studies with different and never definitive results. However, what is certain is that it is no longer possible to underestimate the extent of this phenomenon: through institutional environment, a healthy political competition may only encourage a country growth and on this point, all economic literature agrees. In fact, despite the differences we will find among the mentioned scholars, there is no denying that the economic institutions of a country evidently represent an attraction for foreign investments, investments that are always generative of economic growth. Thus, the problem is to identify how the direct impact of parties competition on the institutional arrangements and then, how much part of the economic development is attributable to improvements in the institutional domain due to a better political competition outcome.

\section{Theoretical Background}

The term political competition has been largely used in different studies to describe different things. One more general interpretation of political competition is "competition for political power. It is a competition to shape and control the content and direction of public policy-rivalry for the capacity to influence or determine official governmental decision-making and action on questions of public policy" (Djeudo, 2013, pag.71). Under a free and competitive democratic society different groups compete to obtain the legal power to govern the political community for a direct control of the government and for the right to formal decide how and for what purposes governmental authority will be used. In this environment, the main source of political conflict/ competition may be identified in the unequal redistribution of costs and benefits deriving from public policy choices. The literature, by analysing political competition's costs and benefits, underlines its crucial role in the institutional process which leads to the policies and behaviours necessary for the realization of investments, technologies, skills and other productive factors progrowth [16-20]. Various authors explain how political competition has a different impact on economic results, in fact, the presence of distorting policies preferences in order to strengthen political power positions and economic rents, the asymmetric information between citizens and representatives, the distributive conflict between groups of citizens and the public investment opportunities features, explain a distorting effect through the political process that can culminate in the creation and consolidation of institutions which block the development and economic growth of a nation.

By considering the economic effects of political competition it is possible to identify three main channels through which political competition influences the institutional efficiency. The first channel revolves around a process of political turnover and is called accountability for incumbents [21-22]. This perspective is founded on inter-temporal perspective of political competition and is strictly correlated with the concept of political accountability. In fact, political competition determines the current behaviour of incumbent through the threats of citizens' substitution of the previous period, so the direct benefit is the increasing level of incumbent's accountability for his action when the level of political competition in the system increases. Another positive effect of the political turnover is the major degree of reciprocity and cooperation between the groups competing for public authority. Because elected officials are aware that they will not hold office forever, they would build "insulating structures" that will reduce the degree of offices sabotage but also decrease 
their effectiveness (De Figueiredo, 2002). Instead, based on turnover perspective, the so-called "political replacement effect" [23-24] represents the main cost of political competition, in fact, in public decision-making processes, the adoption of investments or public changes (innovation), that are economically productive but could destabilizing political system, leads the incumbent to inefficient political decisions for country's development. The second channel through which political competition impact on institutional efficiency is the decentralized political authority and looks at the number of agents that hold the political authority [2526]. The effects of political competition are investigated by using the same models adopted to study market competition in which the level of system's efficiency increases with the increasing of the number of subjects holding political authority. In a "governance market", by favouring the competition of public offer, political decentralization transfers resources, services and functions from inefficient authorities to efficient authorities characterized by limited corruption, pro-market policies, and so on [25,27-31]. Finally, last channel involves electoral politics and concerns the conflict between parties and elites in order to obtain electoral support (Skilling and Zeckhauser [32]; Dixit \& Londregan [33]. In competition between parties and elites the use of "economic power" to achieve electoral support in current period, hinders the adoption of efficient electoral policies in the long run. This mechanism identifies in the earnings' distribution the source of both non-neutrality and losses resulting from reforms. Basically, the electoral policies leading to ex-post improvements in efficiency are not adopted, if ex-ante it is not possible to identify the subjects in charge of the benefits and costs of these reforms [34].

\section{Final Remarks}

All these mentioned works show how in different scenarios, groups in power adopt choices that involve the manipulation of public policies or economic conditions as a strategy for ensuring themselves economic and political power and advantages by reducing the well-being of the other groups. Political institutions directly affect the development of a society: the level of political competition in democratic systems characterizes the political process that determines the choices to adopt more or less efficient policies. In turn, the current level of political competition of a country is determined by the "rules that govern the political game", i.e. by political institutions. Finally, through the process of public choices, political competition leads to a compromise between social costs and benefits, deriving from public policies which, due to various distorting factors, can lead to the development or economic backwardness of a nation. Studying political competition is useful to understand as the mixing of some subjective and normative requirements and the presence of altruistic or opportunistic purposes are able to "humanize" the institutional system, leading it towards dynamics capable or not to improve the social well-being [35-37]. In brief, the asymmetric information between citizens and government, the distributive conflicts between groups of citizens and the characteristics of public investment opportunities show how conflict among parties - through the political process - may culminate in the setting of institutions that have a different impact on economic growth, performance and well-being of a country. However, in democratic systems a higher political competition allows to citizens both to choose the most competent candidates and provide a mechanism for controlling moral hazard by binding governments to forms of responsibility towards citizens [21-22]. From this perspective the competition among parties is the main instrument for monitoring the work of public officials. The electoral race, by improving voter control over possible abuses of elected representatives, increases the voters' utility which may extract information by eliminating any informational rent through the process of political turnover. Furthermore, competition among parties in presence of great electoral uncertainty, in systems with few veto limits, increases the likelihood of a cooperative outcome (De Figueiredo, 2002). In addition, if cooperation's gains are wide, compromises and cooperation are realized among parties and better public plans will be adopted. Moreover, with a high level of political competition ex ante, in order to preserve his political power, the incumbent is strongly incentivized to adopts investments or public policies economically productive in order to obtain electoral consensus [7]. Eventually, during the electoral period parties tend to modify their electoral policies stance working in the same way to get electoral support: therefore, the increases in political competition are associated with ex post lower tax revenue, a higher level of capital spending and a higher probability that a state uses a rightto-work law [19-20]. In summary, by increasing the citizens' power to control the incumbent's political actions and by changing the incentives of politicians, political competition leads ex post to implement policies rise their performance and efficiency.

\section{References}

1. Desmetz H (1967) Toward a theory of property rights. American Economic Review Paper and Proceedings 57: 347-359.

2. Coase R (1937) The Nature of the Firm. Economica 4(16): 386-405.

3. North DC (1987) Institutions, transaction costs and economic growth. Economic Inquiry 25(3): 419-428.

4. Saint-Paul G (2000) The Political Economy of Labour Market Institutions. Oxford University Press.

5. Acemoglu D, Johnson S, Robinson JA (2005) Institutions as a Fundamental Cause of Long-Run Growth. Handbook of Economic Growth 1A: 386-472.

6. Acemoglu D, Johnson S \& Robinson JA (2005) The rise of Europe: Atlantic trade, Institutional Change and Economic Growth. American Economic Review 95(3): 546-579.

7. Acemoglu D, Robinson JA (2002) Economic Backwardness in Political Perspective. NBER Working Paper no 8831.

8. Acemoglu D (2006) Modelling Inefficient Institutions, National Bureau of Economic Research, Working Paper No.11940.

9. Acemoglu D, Robinson JA (2006) Economic Backwardness in Political Perspective American Political Science Review 100(1): 115-131. 
10. Glaeser EL, Shleifer A (2002) Legal origin. The Quarterly Journal of Economics 117(4): 1193-1229.

11. Granovetter M (1985) Economic Action and Social Structure: the problem of Embeddedness. The American Journal of Sociology 91(3): 481-510.

12. Granovetter M (2005) Struttura sociale ed esiti economici. Stato e Mercato 72: 355-382.

13. Putnam RD (1993) Making Democracy Work: Civil Traditions in Modern Italy. Princeton University Press, New Jersey, United States.

14. Fligstein N, Dauter L (2007) The Sociology of Markets. Annual Review of Sociology 33(1): 105-128.

15. Sachs JD (2001) Tropical Underdevelopment. NBER Working Paper No. 8119.

16. Downs A (1957) An Economic Theory of Political Action in a Democracy. Journal of political economy 65(2): 135-150.

17. Wittman D (1973) Parties as Utility Maximizers American Political Science Review 67 (2): 490-498.

18. Hamilton A, Jay J \& Madison J (1966) The Federalist Papers: A Collection of Essays Written in Support of the Constitution of the United States: from the Original Text of Alexander Hamilton, James Madison, John Jay, Selected and Edited by Roy P Fairfield, Baltimore: Johns Hopkins University Press, Maryland, United States.

19. Besley T, Persson T \& Sturm D (2005) Political Competition and Economic Performance: Theory and Evidence from the United States.

20. Besley T, Persson T \& Sturm D (2010) Political Competition, Policy and Growth: Theory and Evidence from the US. Review of Economic Studies 77(4): 1329-1352.

21. Persson T, Roland G, Tabellini G (1997) Separation of Powers and Political Accountability. Quarterly Journal of Economics 112(4): 11631202.

22. Persson T, Roland G \& Tabellini G (2000) Comparative Politics and Public Finance. Journal of Political Economy 108 (6): 1121-1161.

23. Leonida L, Maimone DA \& Navarra P (2013) Testing the Political Replacement Effect: A Panel Data Analysis, Oxford Bulletin of Economics and Statistics, Department of Economics, University of Oxford 75(6): 785-805.
24. Leonida L, Maimone, DA, Marini A \& Navarra P (2015) Political competition and economic growth: A test of two tales Economics Letters, Volume 135(C): 96-99.

25. Rodden J, Rose-Ackerman S (1997) Does Federalism Preserve Markets? Virginia Law Review 83(7): 1521-1572.

26. Drazen A (2000) The Political Business Cycle after 25 Years. NBER macroeconomics annual 15.

27. Friedman P, Taylor B (2011) Entry Barriers and Innovation in the Market for Governance. academia.edu.

28. Persson T, Tabellini G (1994) Is Inequality Harmful for Growth? American Economic Review 84(3): 600-621.

29. Persson T, Tabellini G (2001) Political Institutions and Policy Outcomes What are the Stylized Facts?

30. Weingast BR (1993) Constitutions as Governance Structures: The Political Foundations of Secure Markets. J. Institutional \& Theoretical Econ: 286, 287.

31. Weingast BR (1995) The Economic Role of Political Institutions Market-Preserving Federalism and Economic Development J.L. Econ. \& Org.

32. Skilling D, Zeckhauser RJ (2002) Political Competition and Debt Trajectories in Japan and the OECD. Japan and the World Economy 14(2): 121-135.

33. Dixit A, Londregan J (1995) Redistributive Politics and Economic Efficiency. American Political Science Review 89(4): 856-866.

34. Fernandez R, Rodrik D (1991) Resistance to Reform: Status Quo Bias and the Presence of Individual Specific Uncertainty. American Economic Review 81(5): 1146-1155.

35. Acemoglu D, Robinson JA (2012) Why Nations Fail: The Origins of Power, Prosperity and Poverty. Profile Books Ltd, London, United Kingdom.

36. Desmetz H (1967) Toward a theory of property rights. American Economic Review Paper and Proceedings 57: 347-359.

37. Dolfin M, Knopoff D, Leonida L \& Maimone D (2017) Escaping the Trap of Blocking': A Kinetic Model Linking Economic Development and Political Competition. Kinetic and Related Models 10 (2): 423-443.

\begin{tabular}{l} 
Your next submission with Juniper Publishers \\
will reach you the below assets \\
- Quality Editorial service \\
- Swift Peer Review \\
- Reprints availability \\
- E-prints Service \\
- Manuscript Podcast for convenient understanding \\
- Global attainment for your research \\
- Manuscript accessibility in different formats \\
( Pdf, E-pub, Full Text, Audio) \\
- Unceasing customer service \\
Track the below URL for one-step submission \\
https://juniperpublishers.com/online-submission.php \\
\hline
\end{tabular}

